EDYTA NOWAK-JAMRÓZ

\title{
$Z$ problematyki nieskuteczności prawa - szlachecki konflikt o jazy
}

\section{Aus der Problematik der Ineffektivität des Rechtes - der Adelstreit um Wassersperren}

1. Jazy: budowa, funkcje, konsekwencje. 2. Strony konfliktu. 3. Możliwości legislacyjne. 4. Prawodawstwo. 5. Motywy. 6. Rozstrzygnięcia prawne. 7. Geograficzny zakres obowiązywania uchwalonych konstytucji. 8. Warunki dopuszczalności istnienia i budowy jazu. 9. Sankcje przeciwko naruszającym swobodę żeglugi. 10. Ściganie. 11. Wolność spławu na rzekach granicznych. 12. Wnioski.

1. Wassersperren: ihre Bauweise, Aufgaben, Konsequenzen. 2. Konfliktparteien. 3. Möglichkeiten der Gesetzgebung. 4. Gesetzgebung. 5. Beweggründe. 6. Rechtliche Bestimmungen. 7. Geografischer Geltungsbereich der beschlossenen Gesetze. 8. Bedingungen der Zulassung zur Existenz und zum Bau der Wassersperren. 9. Strafmaßnahmen gegen Behinderungen der freien Flussschifffahrt. 10. Strafverfolgung. 11. Freiheit der Floßerei auf den Grenzflüssen. 12. Schlussfolgerungen.

1.1. W Polsce aż do XIII w. gospodarcze wykorzystanie rzek ograniczało się przede wszystkim do rybołówstwa i transportu. Do uznania rzeki za źródło energii niezbędny był postęp techniczny pozwalający na przekształcenie siły splywającej wody na użyteczny dla człowieka ruch, najczęściej obrotowy. Jednak przeważające równinne ukształtowanie terenu wymagało działań ludzkich wzmacniających leniwy najczęściej bieg rzeki. Spiętrzano więc nurt w najprostszy sposób - przegradzając rzekę. Powstające przy tym konstrukcje określano rozmaicie, nie przejmując się konsekwencją terminologiczną; najczęściej nazywano je tamą, groblą lub jazem ${ }^{1}$. Jedynie legislator dość konsekwentnie wykorzystuje w swych polskojęzycznych regulacjach ostatni z przywołanych terminów, choć nie potrafimy wyjaśnić, czym się akurat w tym względzie kierowal. Teksty lacińskie natomiast wykorzystuja zwroty ogólniejsze: aggera, obstacula, sedes ${ }^{2}$.

${ }^{1}$ Slownik polszczyzny XVI w., t. IX, red. M. Meyenowa, Wrocław 1975, s. 315.

${ }^{2}$ Slownik lacińsko-polski dla prawników i historyków, J. Sondel, Kraków 1997, s. 43, 679, 869. 
1.2. Termin jaz wskazywać mógł budowalę o różnym przeznaczeniu, ale zawsze wznoszoną w poprzek koryta rzeki. Konstrukcja ta ulatwiła połów ryb, które przegroda zmuszała do wędrówek w wąskie przepusty, a tam już same wpadały do zmyślnie konstruowanych pułapek, pozostawiając rybakom jedynie trud wydobycia ich na powierzchnię. Celem przegrodzenia rzeki mogło być także wykorzystanie jej energii do intensywnej pracy, jak obracanie koła mlyńskiego czy uruchamianie folusza. W zależności od przeznaczenia budowano rozmaite przegrody: dla celów rybołówstwa wykorzystywano tzw. jaz krosny (prawdopodobnie byly to rozpięte w otworze jazowym sieci służące do polowu) lub jaz kubel (kosz z kyka lub wikliny umieszczany $w$ otworze jazowym, w który lowiono ryby). Inaczej zupełnie wyglądal jaz kołowy, który był wykonany z kolów spiętrzających wodę ${ }^{3}$.

1.3. Niezależnie jednak od przeznaczenia i konstrukcji wszystkie te przegrody rzeczne negatywnie wpływały na komunikacje wodną; albo uniemożliwiały spływ całkowicie, albo spowolniały go, kiedy trzeba było czekać na otwarcie jazu, z czym wiązały się również opłaty ściągane $z$ podróżujących. To w oczywisty sposób prowadzić musiało do konfliktu między posiadaczami młynów, foluszy i stęp zainteresowanymi budową i utrzymaniem jazów - właścicieli brzegów, a wykorzystującymi rzeki dla celów komunikacyjnych i transportowych. Nie byl to jednak konflikt między handlującym kupiectwem $z$ miast a budująca $w$ swych dobrach młyny czy prowadząca $w$ nich gospodarkę rybacka szlachtą ${ }^{4}$. Wynik takiego konfliktu daloby się łatwo przewidzieć.

2.1. Szlachcic-producent. Budowanie jazów na rzekach przepływających przez majętność szlachcica-producenta to atrakcyjna, dochodowa inwestycja. Trudno się zatem dziwić, że szlachta chętnie sięgała do tej formy gospodarowania, zwłaszcza że mogła wymuszać na ludności poddanej korzystanie wyłącznie z pańskiego młyna poruszanego silami rzeki. Dochody szlacheckie wzrastały, gdy do miast dostarczano produkty rolne przetworzone także dzięki urządzeniom napędzanym energią wodną.

2.2. Szlachcic-handlarz i spedytor. Zalety jazu docenia właściciel. $Z$ chwilą jednak, gdy sam chce spławić swe produkty, każdy jaz napotkany na trasie podróży stwarza wyłącznie kłopoty, zwłaszcza w cudzych dobrach. W XV w. szlachta, mając zagwarantowaną wolność od cła, masowo sprzedaje produkty

${ }^{3}$ Slownik polszczyzny $X V I$ w., t. IX, s. 315.

4 Odrębną zupetnie kwestią jest swoboda żeglugi, którą próbowano ograniczać w celu utrudnienia konkurencji $\mathrm{w}$ handlu, por. np. De fluviis ad navigandum aperiendis praesertim circa Thorunium, Volumina legum [dalej: VL], I, f. 258. 
uzyskiwane we własnych majętnościach. Najtańszym sposobem transportu tychże towarów jest transport wodny. Bywa, że szlachcic, który odniósł tyle korzyści z przegrodzenia rzeki koło własnego domu, w handlowej podróży wodami śródlądowymi napotykać będzie przeszkody, które co prawda też we własnych, ale $\mathrm{z}$ biegiem rzeki niżej położonych, dobrach wznosili jak $\mathrm{i}$ on zasobni szlachcice.

2.3. Adwersarze. Po obu stronach sprzecznych interesów stoi zatem szlachcic $^{5}$. Niekiedy - co wydawać się może paradoksalne - nawet ten sam szlachcic raz jest zwolennikiem funkcjonowania jazu (własnego), by za chwilę stać się przeciwnikiem budowy lub utrzymania jazu cudzego, przegradzającego jego trasę podróży. Właściciel wodnego młyna chcial zachować jaz swój, ale gdy sam spławiał zboże, oczekiwał, a nawet żądał likwidacji uciążliwego dlań jazu sąsiada. Obie strony konfliktu należały zatem (z małymi wyjątkami) do szlachty, dlatego walkę o likwidację lub o utrzymanie przeszkód rzecznych, szlachta stoczy między sobą ${ }^{6}$. W sytuacjach spornych konieczne było odwolanie się do prawa $i$ to ono miało decydować o racji jednej ze stron. A prawodawca znalazł się w sytuacji nader kłopotliwej: nie mógl zaspokoić równocześnie wzajemnie się wykluczających, a więc sprzecznych interesów szlachcica-gospodarza i szlachcica-handlowca.

3. Przystępując do regulacji tej spornej materii ustawodawca miał do wyboru następujące możliwości:

(1) mógł podjąć decyzje o generalnym obowiązku likwidacji jazów na całym splawnym odcinku rzeki;

(2) mógł zachować wolność budowy jazów;

(3) mógł w końcu sięgnąć po kompromis uwzględniający interesy dwóch stron: ograniczyć jedynie wolność budowy jazów przez ustanowienie obowiązku zapewnienia możliwości ich otwarcia, czyli przez zapewnienie swobody splawu.

4. Do 1578 r. wydano dziesięć aktów regulujących prawo budowy i utrzymywania jazów; szczególna aktywność w tym względzie przypadła na czas tzw. sejmów egzekucyjnych, bowiem wówczas właśnie zagadnienie wolności żeglugi stało się jednym $\mathrm{z}$ częściej wysuwanych przez szlachtę postulatów.

${ }^{5}$ Co prawda nie wyłącznie, ale to właśnie udział przedstawicieli tego samego stanu przesądza o szczególnym charakterze konfliktu.

${ }^{6} \mathrm{~W} . \mathrm{Ku}$ ]a, Wisla. Dzieje Polski, [w:] Studia nad gospodarkq, spoleczeństwem i rodzinq $w$ Europie późnofeudalnej, Lublin 1987, s. 62. 
4.1. W interesującej nas kwestii katalog szlacheckich decyzji ustawowych przedstawia się następująco:

- 1447 r. - statut Kazimierza Jegiellończyka?,

- 1496 r. - konstytucja De liberis navigationibus ${ }^{8}$,

- 1511 r. - konstytucja sejmu piotrkowskiego',

- 1532 r. - konstytucja sejmu krakowskiego ${ }^{10}$,

- 1557 r. - statut sejmu warszawskiego"

- 1563 r. - konstytucja sejmu piotrkowskiego $O$ iaziech $^{12}$,

- 1564 r. - konstytucja sejmu warszawskiego Iazy ${ }^{13}$,

- 1565 r. - konstytucja sejmu piotrkowskiego $O$ iaziech ${ }^{14}$,

- 1567 r. - konstytucja sejmu piotrkowskiego Iazy ${ }^{15}$,

- 1578 r. - konstytucja sejmu warszawskiego Iazy ${ }^{16}$.

4.2. Wśród tych przepisów część (akty z lat 1447, 1496, 1511, 1532, 1557, 1564,1567 ) zawierała merytoryczne uregulowania, w innych (akty $z$ lat $1563,1565,1578)$ jedynie przypomniano - co charakterystyczne dla egzekucjonistów - że obowiązujące $w$ sprawie wolności żeglugi statuty winny być wcielane w życie.

5. Interesująco przedstawia się przywoływane uzasadnienie dla wprowadzanych rozstrzygnięć.

Czasem wskazywano po prostu: ...ut libera sit navigatio fluviorum, in statutis dudum descriptorum, respondendum ex unanimi consensu Consiliariorum nostrorum duximus (1532 r.).

Kiedy indziej odwolywano się do swobody żeglugi, gdyż miala ona zapewnić obfitość, dostatek dóbr wszelakich, wbrew partykularnym interesom jednostek: ...per nonnulos multo pluris aestimantes capturam piscium, quam usum publicum et abundatiam necessarium (1447 i 1496 r.).

Poza tym przywiązywano w nich wagę do tak modnej dziś ochrony środowiska naturalnego: ....Non sepibus, sed retibus piscandum sit, ut tenet usus (1511 r.). Jednakże w żadnym $\mathrm{z}$ aktów nie pojawia się wskazanie na

${ }^{7}$ VL, I, f. 152 (1447 r.) - poszczególne akty oznaczamy przez wskazanie roku wydania i tak odwolujemy się do nich w dalszej części opracowania.

${ }^{8}$ VL, I, f. 258.

9 VL, I, f. 375.

$10 \mathrm{VL}, \mathrm{I}, \mathrm{f} .503$.

11 VL, II, f. 608.

${ }^{12} \mathrm{VL}, \mathrm{II}, \mathrm{f} .624$.

$13 \mathrm{VL}$, II, f. 640.

14 VL, II, f. 691.

$15 \mathrm{VL}$, II, f. 727.

16 VL, II, f. 973. 
szkody wynikające $\mathrm{z}$ przegrodzeń rzeki dla sąsiedztwa, gdy nadmiernie wysoka woda zalewała okoliczne pola, choć i w tej mierze podejmowane były rozstrzygnięcia sejmowe ${ }^{17}$.

6. Ustawodawca przyjmował jedną $\mathrm{z}$ dwu wyżej przedstawionych możliwości rozwiązania sporu dotyczącego jazów, ale ani jedno $z$ nich nie dopuszczało moźliwości swobody grodzenia rzek.

6.1. Pierwsza grupa przepisów nakazywała likwidację jazów, o czym stanowiło siedem aktów z lat: 1496, 1532, 1556/57, 1563/64, 1565 i 1567 oraz z 1578 r. $\mathrm{Za}$ takim rozwiązaniem opowiadała się także na sejmie $1550 \mathrm{r}$. część posłów, przedstawiając wśród postulatów wysuwanych w Articuli in conventu Piotrcoviensi Anno 1550 od wszego stanu rycerskiego ad exequendum dane dezyderat dotyczący wolności spławu na polskich rzekach ${ }^{18}$.

6.2. Rozstrzygnięcie kompromisowe przewidywała znacznie skromniejsza część aktów prawnych: utrzymywano istnienie jazów, o ile było to uzasadnione gospodarczo. Jednocześnie trzy przepisy prawne obarczały właścicieli jazów obowiązkiem zapewnienia swobodnego przepływu; wymienić tu należy: statut Kazimierza Jagiellończyka z 1447 r. oraz konstytucje z 1511 i 1567 r.

7.1. Jeśli chodzi o geograficzny zasięg uchwalonych aktów prawnych, to tylko dwa z zachowanych - tj.: statut z 1447 r. i konstytucja z 1496 r. - zawierają imienne wyliczenie rzek, na których miały obowiązywać. Statut z 1447 r. wymieniał: Wisłę, Dniepr, Styr, Narew, Wartę, Dunajec, Wisłokę, Bug, Bruki (?), Wieprz, Tyśmienicę, San, Nidę i Prosnę. Natomiast w akcie z 1496 r. znalazły się jeszcze dodatkowo: Orda (?), Drwęca i Noteć, ale zabrakło nieznanej Bruki. Jednak musimy od razu wskazać, że w obydwu przypadkach nie jest to numerus clausus, gdyż prawodawca uzupełnił swoje wyliczenia dodatkowym zastrzeżeniem: ...et quaecunque alia in Regno nostro consistentia [1477 r.], ...et alia in Regno nostro existentia [1496 r.]. Wynikałoby $\mathrm{z}$ tego, że ostatecznie przepisy dotyczyłyby wszystkich rzek w Królestwie.

7.2. Jeszcze tylko $w$ konstytucji $z 1511$ r. wskazano $z$ nazw rzeki, ale ograniczono się do wymienienia dwóch jedynie największych: Wisły i Warty ${ }^{19}$, uznając słusznie, że zamieszczona kaluzula et alii dostatecznie określa nieograniczoną moc obowiązującą przepisów. W pozostałych konstytucjach

\footnotetext{
${ }^{17}$ Por. np. konstytucję sejmu piotrkowskiego z $1567 \mathrm{w}$ sprawie młyna Mątewskiego wskazującą, że i $w$ tej mierze trudno było wprowadzić w życie sejmową decyzję.

${ }_{18}$ J. S zujski, Dyaryusze sejmów koronnych 1548, 1553 i 1570, t. 1, Kraków 1872, s. 21.

${ }_{19}$...ut fluvii Wisla, Warta et alii.
} 
znajdujemy już tylko sformułowania generalne: ...ut libera sit navigatio fluviorum $[1532 \mathrm{r}$.$] ; ...aby na wolnych rzekach yazy nie byly [1557 \mathrm{r}$.$] ; ...na$ tych wszytkich rzekach, które sq navigabiles [1563/64 r.]; mówi się także o rzekach, któremi spust idzie [1567 r.].

Widzimy zatem, że z jednej strony zakaz grodzenia dotyczyć ma wszystkich rzek na terenie państwa, z drugiej zaś strony okazuje się, że prawodawca ogranicza swą decyzję tylko do pewnej kategorii rzek - tych, którymi idzie spust, czyli po prostu splawnych. W końcu odwołanie się do sformułowania, że wolny splaw ma być na tych rzekach, które są wolne, niewiele wnosi do wyjaśnienia interesującej nas kwestii, skoro nie wiemy, które rzeki są wolne.

7.3. W gruncie rzeczy zatem żadne $\mathrm{z}$ przyjętych rozwiązań nie było $\mathrm{z}$ legislacyjnego punktu poprawne. Wedle bowiem statutu Kazimierza Jagiellończyka obowiązywać miala zasada, że brzegi rzek stanowią królewską własność, a $w$ konsekwencji nie podlegaja prywatyzacji dla realizacji indywidualnego interesu: ...flumina nostra Regni nostro Poloniae [...] cum suis alveis Regia nostra sunt $[1447 \mathrm{r}$.]. Trudno więc mówić o rozróżnieniu na rzeki publiczne i prywatne - jak chce Pawel Dąbkowski ${ }^{20}$. Zakaz obejmować miał wszystkie rzeki, zaś wyjątki były dopuszczone jedynie w niektórych aktach, w określonych sytuacjach. Wówczas funkcjonowanie jazu nie było sprzeczne z prawem i nie pociągało za sobą sankcji $\mathrm{i}$ konieczności placenia odszkodowania.

7.4. Tak więc należy przyjąć, że - zgodnie z królewską wolą - właściciela brzegów obowiązuje w Polsce wolność żeglugi rzecznej co najmniej od 1447 r. Nie ma problemu imiennego wskazywania rzek, na których istnieje wolność splawu; ma ona charakter generalny. O tym jednak prawodawca nie zawsze pamiętal i zastrzegal, ze tworzone przezeń regulacje dotyczą rzek wskazanych we wcześniej wydanych statutach, czyli... odnoszą się do wszystkich splawnych. Należałoby się jeszcze zastanowić nad warunkiem, którego wypełnienie legalizowałoby funkcjonowanie jazu.

8.1. Najważniejszym czynnikiem przesądzającym o obowiązywaniu zakazu grodzenia rzeki jest jej zdolność do pełnienia funkcji drogi komunikacyjnej. Tylko spławna rzeka objęta jest interesującymi nas przepisami. Warto przy tam zauważyć, że żaden przepis nie ustalał precyzyjnie, kiedy i jaką rzekę należy uznać za spławną. Przyjmujemy zatem, że przesądzała o tym praktyka: wszędzie więc, gdzie na wodzie pojawiala się zdatna do transportu tratwa, tam należało zapewnić jej wolny splaw: ...per ques naves onustae et trabes contexte sive strues, que vulgo traffty vocantur libere devehi possint $\left[\begin{array}{lll}1511 & \mathrm{r} .]\end{array}\right]$ Dopiero bowiem wtedy, gdy płynący rzeką natknął się na przeszkodę,

${ }^{20}$ P. Dąbkowski, Prawo prywatne polskie, t. 1, Lwów 1913, s. 262. 
mogło dojść do konfliktu i wszczęcia postępowania przed sądem. Trudno wyobrazić sobie, że ktokolwiek (np. starosta) podejmował się na wszelki wypadek kontroli spławności rzeki przepływającej przez terytorium podległe jego władzy.

8.2. W decyzjach prawodawcy widać, co prawda, brak konsekwencji, bowiem $\mathrm{z}$ jednej strony ustanawia on obowiązek zrzucenia wszelkich przegród na rzekach i zakazuje budowy nowych (akty $\mathrm{z}$ lat: 1496, 1532, $1557,1564,1565,1567,1578$ ), ale $\mathrm{z}$ drugiej - co jakiś czas wskazuje, że dopuszcza się zachowanie jazu, albo nawet konstrukcję nowego, jeśli tylko zapewni się bezpieczny przejazd. To charakterystyczne: ustawowe zezwolenie na istnienie nie stwarzających komunikacyjnych utrudnień jazów wydane zostaje w 1511 r.: ...ideo statuimus, ut predicta flumina, sub poena sexaginta marcarum purgentur, et in eis ostia fiant, per que naves onustae [...] libere devehi possint, quod [...] hinc ad medium quadragesimae fieri debent. I ponowiono je, nawiązując do wcześniej wydanych statutów, po kolejnych decyzjach nakazujących bezwzględne zlikwidowanie wszelkich przegród: $A c z$ iazy na rzekach, któremi spust idzie, sa konstytucjami pokażone, a wszakże przychylajac sie dawnym statutom, ktoby iaz mieć chcial, aby $w$ nim śloże albo wrota czynil: tedy dopuszczamy, aby powinien $w$ iazie swym śloży, abo wrota przestronne uczynić, żeby wolnie a bezpiecznie towary wszelakie schodzily [1567 r.].

8.3. $\mathrm{Z}$ przepisów tych wynika zatem jasno, że niezależnie od sytuacji - czy jaz na rzece spławnej już istnieje od dawna, czy też ma dopiero powstać - zawsze jaz może być legalny, o ile jego konstrukcja umożliwia przepuszczanie spływających transportów, a więc gdy przewidziano w niej wrota lub inną śluzę.

8.4. Nie jesteśmy natomiast $w$ stanie rozstrzygnąć, czy ustawodawca w dwóch swych decyzjach (z lat 1511 i 1567) wprowadzal rozwiązania odmienne od dotychczasowych, a więc czy $w$ pozostalych przypadkach traktowano decyzje sejmowe jako powszechnie obowiązujący zakaz przegradzania rzek, niezależnie od tego, czy budowla uniemożliwia spław, czy też zapewnia jego swobodę. Być może sformułowań poszczególnych aktów nie traktowano dosłownie, uznając, że ich celem jest - jak to wynika z niektórych uzasadnień - wolność żeglugi, a nie zakaz inwestycji wodnych. Pewnych wskazówek w tym zakresie można szukać $w$ przepisach mających uchylić omawiane tu postanowienia.

9.1. Ustawowo gwarantowaną sobodę żeglugi można było naruszać w rozmaity sposób. Nie interesją nas $w$ tym miejscu ograniczenia prawne 
(np. wynikający z miejskich przywilejów obowiązek składu), przede wszystkim zajmiemy się ograniczeniami faktycznymi, czyli budową na rzece konstrukcji uniemożliwiających wykorzystanie jej jako szlaku transportowo-komunikacyjnego. Naruszenie tej kategorii przepisów następować mogło w dwojaki sposób: albo rzeka przegrodzona została $w$ taki sposób, że spław był fizycznie niemożliwy, albo istniejące w jazie wrota pozwalały na komunikację między przegrodzonymi odcinkami rzeki, ale właściciel jazu chcial pobierać opłaty za przepuszczenie podróżujących.

9.2. Najstarsza regulacja wprowadziła sankcję za obie przewidziane wyźej sytuacje. Statut z 1447 r. zakazywal poboru opłat za możliwość przepłynięcia przez jaz i przewidywał droge odszkodowawczą w sytuacji, gdy wbrew przepisom pozostawiono jaz bez zapewnienia możliwości przepływu. W obu przypadkach za naruszenie postanowień przepisu grodziła kara siedemdziesiąt. W $1496 \mathrm{r}$. prawodawca przyjąl to samo stanowisko, by zmienić je juź w $1511 \mathrm{r}$. W późniejszych aktach prawnych nie ma uregulowań dotyczących sankcji za niezgodny z prawem pobór opłat za otwarcie jazu. Przewidywały one możliwość karania niesubordynowanych właścicieli tylko w wypadku pozostawienia jazu bez możliwości przepływu. Warto wskazać także regulację, która różni się $w$ tym zakresie od pozostałych. Za budzące wątpliwości rozwiązanie w zakresie sankcji uznajemy postanowienie konstytucji z 1532 r., która odwoływała się $w$ tej mierze do uprzednich rozwiązań prawnych, jednakże bez dokładnego wskazania aktu.

9.3. Niektóre akty utrzymanie jazów obwarowują dodatkowymi rygorami. Przykładem może tu być konstytucja sejmu piotrkowskiego z 1511 r., która gwarantowała wolny spław Wisłą i Wartą. Regulacja ta przewidywała możliwość pozostawienia jazów na dwóch wymienionych rzekach, jeżeli spełnione zostaną dwa warunki: po pierwsze - jaz miał służyć spiętrzeniu wody niezbędnej do pracy młyna, a po drugie - musiała istnieć techniczna możliwość otwarcia jazu. Realizacja przepisów ustawodawczych była utrudniona głównie przez ich nierespektowanie.

9.4. Przestępstwa związane $\mathrm{z}$ jazami zagrożone były karami majątkowymi. Ponosić je miał wlaściciel jazu, dla którego ustawodawca przewidywal dwie sankcje: karę pieniężną nakładaną na sprawcę oraz obciążający go obowiązek odszkodowawczy.

W poszczególnych regulacjach wysokość kary określano rozmaicie, ale dostrzegamy zdecydowany trend do jej podwyższania. Początkowo (1447 r.) nie ma ani słowa o sankcji pieniężnej, jakiej ma podlegać naruszający, przez budowę jazu, wolność spławu. Następnie (1496 r.) za naruszenie przepisów o jazach przewidziano karę siedemdziesiqt. W kolejnych konstytucjach 
obserwujemy już systematyczne podwyższanie kar: w 1511 r. przewiduje się karę wynoszącą 60 grzywien, w akcie z 1557 r. mowa o karze 100 grzywien, a w końcu (1563/64 r.) podniesiono ją aż o 100\% - do 200 grzywien.

Możliwość skorzystania z drogi odszkodowawczej przewidziano w aktach prawnych jeszcze przed określeniem kary pieniężnej; mówiła o niej już najstarsza regulacja (z 1447 r.). Wysokość odszkodowania, zależąca od rozmiaru szkody, musiała być określana odrębnie w każdym przypadku, a poszkodowany zawsze mógł zawrzeć ugodę.

10. Niezastosowanie się do rozstrzygnięć dotyczących jazów było przestępstwem publicznym, wymierzonym przeciw panującemu. Czyn ten ścigany był $\mathrm{z}$ urzędu, a obowiązek wszczęcia postępowania przed właściwym sądem spoczywał na staroście.

Legitymacja procesowa przysługiwała każdemu, kto poniósł szkodę przez zaniechanie wykonania przepisów. Postępowanie to mogło zostać wszczęte również $\mathrm{z}$ urzędu ${ }^{21}$.

Sądem wlaściwym w sporach związanych $\mathrm{z}$ naruszeniem wolności żeglugi początkowo był sąd wiecowy. Jednak brak skuteczności w egzekwowaniu wydanych przezeń wyroków spowodowal, że statutem z 1557 r. przyznano właściwość w tych sprawach sądowi grodzkiemu. Przekazanie kompetencji staroście związane bylo zapewne $\mathrm{z}$ nadzieją na zwiększenie efektywności wykonania wyroku.

11. Odrębnym, acz równie skomplikowanym był problem spławności rzek granicznych. Kontrowersje w tym względzie obejmują strefy wplywów czterech państw: Królestwa Polskiego, Litwy, Marchii Brandenburskiej oraz Księstwa Pomorskiego ${ }^{22}$. Jeśli chodzi o granicę z Litwą, to niezadowolenie właścicieli folwarków budziły jazy zbudowane na Bugu. Regulacje dotyczące rzeki sa sprzeczne. Statut z 1447 r. i konstytucja z roku 1496 gwarantowaly wolny spław Bugiem. Tymczasem sejm w konstytucji 1563/64 r. wprowadził wyjątek $^{23}$, nie obejmując Litwy nakazem zrzucenia jazów. Ustawodawca uzasadnial swą decyzję tym, iż ze względu na geograficzne usytuowanie rzeki (większa część Bugu płynie w Wielkim Księstwie Litewskim) i wobec

${ }^{21}$ Konstytucja z $1564 \mathrm{r}$.

${ }^{22}$ M. B ogucka, H. Sams on owicz, Struktury spoleczne Gdańska w XV-XVII wieku na tle przemian $w$ handlu baltyckim, [w:] Studia nad gospodarka, spoleczeństwem i rodzinq w Europie późnofeudalnej, Lublin 1987, s. 140; Encyklopedia historii gospodarczej Polski do 1945 , t. I, red. A. Mączak (autor A. Olejarczuk), Warszawa 1981, s. 282; A. W y cza ński, Polska Rzeczq Pospolitq szlacheckq, Warszawa 1991, s. 54; J. T o polsk i, Gospodarka Polska a Europejska w XVI-XVIII wieku, Poznan 1977, s. 85-96.

${ }^{23} \mathrm{VL}, \mathrm{II}, \mathrm{f} .640$. 
braku regulacji prawnych na Litwie nakazujących likwidacje jazów, konstytucja Iazy nie może objąc tej rzeki. Ustalenie stanu prawnego dotyczącego jazów na rzekach Wielkiego Księstwa Litewskiego zostało zapowiedziane na najbliższy sejm, jednak podobną do obowiązującej w Koronie regulację wprowadzono na Litwie dopiero konstytucją z $1601 \mathrm{r}^{24}$

W 1563/64 r. uchwalono również konstytucję dotyczącą Warty i Noteci ${ }^{25}$. $\mathrm{Na}$ rzekach tych, choć objętych regulacją statutu Kazimierza Jagiellończyka, w praktyce nie zapewniono swobodnego przepływu. Problem był złożony, ponieważ obie rzeki płynęły nie tylko przez terytorium Królestwa Polskiego, lecz także przez Marchię Brandenburską i Księstwo Pomorskie. Realizując postulaty szlachty, zdecydowano o wyborze komisarzy, którzy zostali upoważnieni do rozmów z margrabiami i książętami pomorskimi ${ }^{26}$. Najbliższy sejm, na podstawie złożonych przez komisarzy sprawozdań, miał rozstrzygnąc sprawę spływu i budowania jazów.

12. Szlachecki konflikt o jazy znakomicie ilustruje rzeczywistość, w której się toczył. Prawodawcą w państwie była szlachta. Problem jednak tkwił w tym, że szlachta potrzebowała różnych, przeciwstawnych uregulowań tej kwestii. Punkt widzenia szlachcica zmieniał się wraz $\mathrm{z}$ działalnością, jaką w danym momencie prowadził. Wolność żeglugi była zatem prawnie, acz nieskutecznie zastrzeżona. Szlachcic potrzebowal jej tylko okresowo. Gdy przestawał spławiać zboże, ważniejsza była dla niego możliwość utrzymania młyna czy folusza. Podejmowane przez ustawodawcę próby kompromisowego rozwiązania problemu jazów nie powiodly się, wiązały się bowiem $\mathrm{z}$ dodatkowymi nakładami, których szlachta nie chciała ponosić, ponieważ nie zależało jej na ułatwianiu życia innym. Zaś wobec słabości bracchium regale, niewydolności organów egzekucyjnych, wymuszenie respektowania stanowionych przepisów okazało się niemożliwe.

24 VL, II, f. 29.

25 VL, II, f. 640 .

25 Źródlopisma do dziejów Unii Korony Polskiej i Wielkiego Ksiestwa Litewskiego, cz. II, Poznań 1861, s. 102. 